\title{
Effect of mannan oligosaccharide addition to whole milk on growth and health of Holstein calves
}

\author{
Can Uzmay, Asım Kılıç, Ibrahim Kaya, Hülya Özkul, Sibel Soycan Önenç and Muazzez \\ Polat
}

Department of Animal Science, Faculty of Agriculture, Ege University, Bornova-Izmir, Turkey

\begin{abstract}
The purpose of this study was to investigate the effect of mannan oligosaccharide (MOS) mixed in the whole milk on the growth and health of calves. Forty Holstein calves (20 male, 20 female) were randomly assigned, within sex, to one of two groups at $5 \mathrm{~d}$ of age. Calves were fed fresh, warm whole milk (control) or fresh, warm whole milk supplemented with MOS ( $4 \mathrm{~g}$ of Bio-Mos per calf daily at a.m. feeding). Calves were fed $4 \mathrm{~L}$ of whole milk per day in two equal feedings for 6 weeks. Pelleted calf starter and fresh water were available ad libitum during the experiment. No hay was fed. Body weights (BW) were measured at the beginning of the experiment and then weekly till the end of the experiment. Height at withers, heart girth, withers to pins, and point of shoulder to pins were measured at the beginning and at the end of the experiment. Fecal fluidity scores and respiratory condition were monitored daily. Intake of whole milk was similar between the groups $(P>0.10)$. Although there was no significant difference in starter intakes $(P>0.10)$, calves in MOS treatment consumed $19.9 \%$ more calf starter than calves in control diet $(499.2 \mathrm{vs.} 416.5 \mathrm{~g} / \mathrm{d})$ for 26 to $46 \mathrm{~d}$ of age. BW gains for various age periods were unaffected by treatment $(P>0.10)$. However, calves in MOS treatment gained $11.2 \%$ more BW than calves in control diet ( $627.4 \mathrm{vs.} 564.2 \mathrm{~g} / \mathrm{d})$ from 26 to $46 \mathrm{~d}$ of age. Skeletal growth and feed efficiencies were similar for calves in both groups. No respiratory problems in calves in both groups occurred during the experiment. Fecal fluidity scores, percent calf days with scours and percent calf days treated for scours were unaffected by treatment $(P>0.10)$. However, calf scours was a common problem especially during the first 3 weeks of the experiment. The reason for this may have been that calf scours had been a common problem at the location of the experiment for many years. This suggests that there must have been a significant enteric challenge for calves at this location. Even under these stressful conditions, MOS in whole milk did not elicit an improvement in enteric health in the circumstances of this location. Although there were no significant differences between the groups, the results suggest that starter intake and consequently BW gain from 26 to $46 \mathrm{~d}$ of age tended to be improved in calves in MOS group compared with calves in control group.
\end{abstract}

Keywords: calf, mannan oligosaccharide, whole milk, performance, calf scours 


\section{Zusammenfassung}

\section{Einfluss von Mannan-Oligosaccharid-Zusatz in Vollmilch auf Wachstum und Gesundheit von Holstein Kälbern}

Ziel dieser Arbeit war es, den Einfluss von in die Vollmilch zugesetzten MannanOligosaccharid (MOS) auf das Wachstum und die Gesundheit von Kälbern zu untersuchen. Vierzig Holstein Kälber (20 männlich, 20 weiblich) wurden im Alter von 5 Tagen unter Berücksichtigung des Geschlechts zufällig ausgesucht und jeweils einer von 2 Gruppen zugeteilt. Den Kälbern wurde frische warme Vollmilch (Kontrollgruppe) oder frische warme Vollmilch mit MOS-Zusatz (morgens täglich $4 \mathrm{~g}$ Bio-MOS pro Kalb) verabreicht. Den Kälbern wurde für eine Versuchsdauer von 6 Wochen pro Tag 4 I Vollmilch in zwei gleichen Portionen angeboten. Während des gesamten Versuches standen pelletiertes Kälberaufzuchtfutter und frisches Wasser zur freien Aufnahme zur Verfügung. Heu wurde nicht gefüttert. Das Gewicht wurde zu Beginn des Versuches und dann bis zum Ende des Versuches wöchentlich erfasst. Widerristhöhe, Brustumfang und Körperlänge (gemessen vom Schultergelenk bis zum Sitzbeinhöcker bzw. vom Widerrist bis zum Sitzbeinhöcker) wurden zu Beginn und am Ende des Versuches gemessen. Die Konsistenz des Kotes und der Zustand der Atmungswege wurden täglich kontrolliert. Die Vollmilchaufnahme war in beiden Gruppen ähnlich $(P>0.10)$. Obwohl in Bezug auf Aufzuchtfutteraufnahme zwischen den Gruppen kein signifikanter Unterschied bestand, haben 26-46 Tage alte Kälber in der MOS-Gruppe 19.9\% mehr Aufzuchtfutter aufgenommen als Kälber in der Kontrollgruppe (499.2 vs. 416.5 g/Tag). Es war kein signifikanter Einfluss des MOS-Zusatzes auf die Gewichtszunahmen in verschiedenen Altersabschnitten festzustellen ( $P>0.10)$. Jedoch wiesen 26-46 Tage alte Kälber in der MOSGruppe $11.2 \%$ höhere Tageszunahmen im Vergleich zu Kälbern in der Kontrollgruppe (627.4 vs. $564.2 \mathrm{~g} / \mathrm{Tag}$ ) auf. Skelettwachstum- und Futterverwertung waren ähnlich für Kälber in beiden Gruppen. Es traten während des Versuches keine Atemwegsprobleme bei Kälbern in beiden Gruppen auf. Die Behandlung (MOS-Zusatz) hatte keinen Einfluss auf die Kotkonsistenzpunkte, auf den Anteil an Tagen mit Durchfall und auf die Behandlungstage wegen Durchfalls $(P>0.10)$. Allerdings war Kälberdurchfall ein häufig auftretendes Problem besonders in den ersten 3 Wochen des Versuches. Dies könnte darauf zurückgeführt werden, dass im Versuchsort Kälberdurchfall seit vielen Jahren ein verbreitetes Problem darstellt. Sogar unter diesen schwierigen Bedingungen konnte der MOS-Zusatz in der Vollmilch keine Verbesserungen der Darmgesundheit hervorrufen. Obwohl zwischen den Gruppen keine signifikanten Unterschiede vorhanden waren, deuten die Ergebnisse darauf hin, dass im Alter von 26-46 Tagen die Aufzuchtfutteraufnahme und infolgedessen die Gewichtszunahme bei Kälbern der MOS-Gruppe eine tendenzielle Verbesserung im Vergleich zu Kälbern der Kontrollgruppe aufweist.

Schlüsselwörter: Kalb, Mannan-Oligosaccharid, Vollmilch, Wachstum, Kälberdurchfall 


\section{Introduction}

Various dietary supplements have been used in ruminant animal production for several purposes (Kaufhold et al. 2000, Quigley et al. 2002, Ayışığı et al. 2005, Holló et al. 2008, Ardalan et al. 2010). Antibiotics have been used as animal feed additives for the past several decades to improve health and performance of animals. In the dairy industry, antibiotics are extensively used in milk replacer (MR) for calves (Heinrichs et al. 1995, Newman 2002a). However, because of the potential development of antibiotic-resistant bacteria in animals and humans some researchers, consumers, and government officials promote the elimination of sub-therapeutic antibiotic use in animal production (Newman 2002a, Newman 2002b). Therefore, alternatives to antibiotic growth promoters in animal production have become important. Oligosaccharides have been proposed as one of the alternatives to antibiotics. Most commonly available oligosaccharides are fructooligosaccharides (FOS) and mannan oligosaccharides (MOS), and another potential product is galactosyl-lactose (Quigley 2004).

Oligosaccharides support competitive exclusion in several ways. FOS support the growth of beneficial intestinal bacteria such as bifidobacteria and lactobacilli and inhibit pathogens (Newman 2002b). MOS are obtained from the cell wall of Saccharomyces cerevisiae (Spring et al. 2000, Grieshop 2003). MOS occupy the binding sites on the intestinal pathogens. Unfavourable gram-negative bacteria such as Escherichia coli and Salmonella use mannosespecific (type-1) fimbriae to attach to and then colonize the intestinal wall. Pathogens that express type-1 fimbriae adsorb to the MOS instead of attaching to intestinal epithelium and, therefore, move through the intestine without colonization (Spring et al. 2000, Fairchild et al. 2001, Parks et al. 2001). MOS may also stimulate the immune function (Newman 2002a, Grieshop 2003).

Studies investigating the effect of dietary MOS on health and growth of calves are generally scarce. Several studies reported that addition of MOS (2 to $4 \mathrm{~g} / \mathrm{calf} / \mathrm{d}$ ) to MR improved body weight (BW) gain (Newman et al. 1993, Jacques \& Newman 1994, Nippei Feed Company 1996, Dvorak et al. 1997a, Dvorak et al. 1997b) and increased starter intake of calves (Jacques \& Newman 1994, Dvorak et al. 1997a, Heinrichs et al. 2003, Terré et al. 2007). On the other hand, some research showed that addition of MOS (4 or $6 \mathrm{~g} / \mathrm{calf} / \mathrm{d}$ ) to MR did not change BW gain of calves (Heinrichs et al. 2003, Terré et al. 2007, Hill et al. 2008).

Some research indicated that addition of MOS to MR reduced scours in calves (Nippei Feed Company 1996, Heinrichs et al. 2003). However, Terré et al. (2007) found no difference in the incidence of loose feces, and Hill et al. (2008) found no difference in fecal scores and in days with abnormal fecal scores of calves fed MR with MOS or no additive. Newman et al. (1993) reported no difference in concentrations of fecal coliforms or clostridia, and Terré et al. (2007) reported no difference in Escherichia coli fecal counts in calves fed MR with MOS or no supplementation.

Warm whole milk is used extensively in feeding of calves in Turkey. The objective of this study was to investigate the effect of MOS mixed in the whole milk on growth and health of Holstein calves. 


\section{Materials and methods}

Forty Holstein calves (20 male, 20 female) born between September 2004 and February 2005 in the Agricultural Faculty Farm of Ege University, Turkey were randomly assigned, within sex, to one of two groups at $5 \mathrm{~d}$ of age. Experiment was carried out at the calf-rearing unit in the Agricultural Faculty Farm of Ege University. This rearing unit was established outside and consisted of 16 individual calf pens.

Calves were fed colostrum for $3 \mathrm{~d}$ and then separated from their dams and placed in individual pens. On the 5th day, calves were switched to their respective liquid diets. Calves were fed fresh, warm whole milk (control) or fresh, warm whole milk supplemented with MOS (4 g of Bio-Mos [Alltech, Inc., KY, USA] per calf daily at a.m. feeding). The experiment continued for 6 weeks.

Calves were fed $4 \mathrm{~L}$ of whole milk per day from a bucket in two equal feedings at 08:00 and 18:00 h for 6 weeks. Whole milk consumption was monitored daily. Pelleted calf starter and fresh water were available ad libitum during the experiment (from d 5 to 46 of age). Intake of calf starter was measured regularly. No hay was offered throughout the experiment. Calves were weighed at the beginning of the experiment and then weekly till the end of the experiment. Height at withers, heart girth, withers to pins, and point of shoulder to pins were measured at the beginning and at the end of the experiment. Fecal fluidity scores were monitored daily on a scale of 1 to 4 (1=normal, $2=$ soft, $3=$ runny, and $4=$ =watery) and respiratory condition was also recorded daily on a scale of 1 to 6 (1=normal, $2=$ runny nose, 3 =heavy breathing, 4=cough-moist, $5=$ cough-dry, and $6=$ fever) according to Larson et al. (1977). Calves with scours were treated with antibiotics by oral or i.m. routes. Use of antibiotics and other drugs was recorded for each calf.

Samples of whole milk and calf starter were collected at different periods of the experiment for analysis of nutrient composition (Table 1). Whole milk samples were analysed for dry matter (DM) and ash using the Gravimetric method, for protein using the Kjeldahl method, for fat using the Gerber method, and for lactose using the polarimetric method (Oysun 2001). Samples of calf starter were analysed for DM, crude protein, crude fat, crude fiber (the Lepper method), and crude ash using the Weender method (Naumann \& Bassler 1993).

Table 1

Composition of whole milk and calf starter

\begin{tabular}{lcc}
\hline Item & Whole milk & Calf starter \\
\hline DM, \% & 11.98 & 89.98 \\
Crude protein, \% & 3.16 & 18.11 \\
Crude fat, \% & 3.50 & 3.31 \\
Crude fiber, \% & - & 6.59 \\
Lactose, \% & 4.58 & - \\
Crude ash, \% & 0.66 & 6.10 \\
ME, MJ/kg DM & - & 12.41 \\
\hline
\end{tabular}

Data were analysed statistically using the least-squares method as applied in the LSMLMW program by Harvey (1987). The following general model was used to analyse intake, growth, feed efficiency, and calf scours data: 


$$
Y_{i j k}=\mu+t_{i}+s_{j}+(t \cdot s)_{i j}+e_{i j k}
$$

where $Y_{i j k}$ is the observation, $\mu$ is the overall mean, $t_{i}$ is the effect of the $i$-th treatment (diet), $s_{j}$ is the effect of the $j$-th sex, $(t \cdot s)_{i j}$ is the interaction due to the combination of the $j$-th sex with the $i$-th treatment and $e_{i j k}$ is the error term.

Initial BW was used as a covariate in the analysis of BW and BW gains for various periods, except in the analysis of initial BW. Initial height at withers, heart girth, withers to pins, and point of shoulder to pins measurements were used as a covariate in the analysis of relevant data.

\section{Results and discussion}

Feed intake, growth, and feed efficiency

Whole milk was fed to calves in both groups at a constant amount (4 L/calf/d) for 6 weeks. Few acceptability problems were observed. Five calves in control group and 8 calves in MOS group refused small amounts of whole milk offered during the first week. Based on the calves refusing whole milk, means for amount refused during the first week were $5.8 \%$ and $10.8 \%$ for control and MOS treatments, respectively.

Least squares means for whole milk, calf starter and DM intakes of calves are given in Table 2 .

Table 2

Least squares means for whole milk, calf starter and DM intakes of calves for various age periods

\begin{tabular}{lcccc}
\hline Trait & Control & MOS & SE & $P$ \\
\cline { 1 - 2 } No. of calves & 20 & 20 & & \\
\cline { 1 - 2 } Whole milk intake, kg/calf/d & & & & \\
5 to 25 d & 4.09 & 4.04 & 0.02 & 0.14 \\
26 to 46 d & 4.10 & 4.10 & 0.00 & 0.32 \\
5 to 46 d & 4.09 & 4.08 & 0.01 & 0.47 \\
Calf starter intake, g/calf/d & & & & \\
5 to 25 d & 108.8 & 122.1 & 14.7 & 0.53 \\
26 to 46 d & 416.5 & 499.2 & 51.2 & 0.26 \\
5 to 46 d & 262.8 & 310.7 & 31.7 & 0.29 \\
DM intake from whole milk, g/calf/d & & & & \\
5 to 25 d & 487.1 & 481.6 & 2.6 & 0.15 \\
26 to 46 d & 489.6 & 490.0 & 0.3 & 0.32 \\
5 to 46 d & 488.4 & 486.0 & 1.4 & 0.22 \\
DM intake from starter, g/calf/d & & & & \\
5 to 25 d & 97.9 & 110.0 & 13.2 & 0.52 \\
26 to 46 d & 374.8 & 449.3 & 46.1 & 0.26 \\
5 to 46 d & 236.4 & 279.6 & 28.6 & 0.29 \\
Total DM intake, g/calf/d & & & & \\
5 to 25 d & 584.9 & 591.5 & 13.7 & 0.74 \\
26 to 46 d & 864.3 & 939.3 & 46.0 & 0.26 \\
5 to 46 d & 724.9 & 765.6 & 28.8 & 0.32 \\
\hline
\end{tabular}

Intake of whole milk was similar between the groups. Mean DM intakes from whole milk for d 5 through 46 were 488.4 and $486.0 \mathrm{~g} / \mathrm{d}$ for calves in control and MOS diets, respectively. 
Although there were no significant differences in starter intakes for various age periods, calves in MOS treatment consumed $19.9 \%$ more calf starter than calves in control diet (499.2 vs. $416.5 \mathrm{~g} / \mathrm{d}$ ) for $\mathrm{d} 26$ through 46. Jacques \& Newman (1994) also reported that starter intake tended to be higher for Holstein calves given MOS in MR. Holstein calves receiving MOS in MR consumed significantly more (14.2\%) calf starter in another study (Dvorak et al. 1997a). Heinrichs et al. (2003) reported that consumption of calf starter increased at a faster rate in Holstein calves fed MOS in MR, and these calves consumed more starter during week 6 after weaning at week 5 than those fed antibiotics in MR. Terré et al. (2007) found that starter intake of Holstein calves tended to be greater during the pre-weaning period, and was greater during the week after weaning in MOS group compared with control group. In a recent study by Hill et al. (2008), addition of FOS or MOS to MR did not affect starter intake of Holstein calves.

Mean initial BW ( $5 \mathrm{~d}$ of age) for calves in control and MOS groups were 43.02 and $42.90 \mathrm{~kg}$, respectively (Table 3). Mean BW at d 25 (49.11 vs. $48.64 \mathrm{~kg})$ and at d $46(60.96 \mathrm{vs.} 61.81 \mathrm{~kg})$ did not differ between control and MOS groups. Mean daily BW gains from d 5 to 25 , d 26 to 46 , and $d 5$ to 46 were also unaffected by treatment. However, calves in MOS treatment gained $11.2 \%$ more BW (627.4 vs. $564.2 \mathrm{~g} / \mathrm{d}$ ) than calves in control diet from d 26 to 46 . Tendency for improved BW gain in calves in MOS treatment during 26 to $46 \mathrm{~d}$ of age must have resulted from increased intake of starter of calves in MOS group during this period. Skeletal growth (height at withers, heart girth, withers to pins, and point of shoulder to pins) was similar for calves in both groups (Table 3). Heinrichs et al. (2003) also found no significant differences in skeletal growth and BW gain in Holstein calves fed MR supplemented with antibiotics, MOS, or no additive. Terré et al. (2007) also showed no differences in BW gain in calves in MOS or control groups. Similarly, Hill et al. (2008) reported that neither MOS nor FOS improved BW gain in calves. However, Newman et al. (1993) and Dvorak et al. (1997a) reported that addition of MOS to MR increased BW gain significantly in Holstein calves. Moreover, Quigley et al. (1997) found that inclusion of galactosyl-lactose (a trisaccharide) to MR increased BW gain in Holstein bull calves. BW gain of 10-week old veal calves tended to be higher when calves were fed liquid diet supplemented with FOS ( $10 \mathrm{~g} / \mathrm{calf} / \mathrm{d})$ compared with no supplementation (Kaufhold et al. 2000). BW gain in Holstein bull calves fed additive containing spray-dried bovine serum and FOS in MR tended to be increased from d 29 to 56 (Quigley et al. 2002).

Feed efficiencies (DM intake/BW gain) were not different between the groups (Table 3). Hill et al. (2008) also found that addition of MOS or FOS to MR did not change feed efficiency in calves. However, Nippei Feed Company (1996) and Dvorak et al. (1997b) reported that addition of MOS to MR improved feed efficiency in calves. Efficiency of feed utilization for BW gain of calves tended to be improved by inclusion of galactosyl-lactose (Quigley et al. 1997) or additive containing spray-dried bovine serum and FOS to MR (Quigley et al. 2002).

Efficiency of feed utilization increased with advancing age. Mean feed efficiencies for $\mathrm{d} 5$ to 25 were 2.15 and 2.46 and for $\mathrm{d} 26$ to 46 were 1.57 and 1.54 for calves in control and MOS diets, respectively (Table 3 ). 
Table 3

Least squares means for BW, BW gains, skeletal growth and feed efficiencies of calves for various age periods

\begin{tabular}{|c|c|c|c|c|}
\hline Trait & Control & MOS & SE & $P$ \\
\hline No. of calves & 20 & 20 & & \\
\hline \multicolumn{5}{|l|}{ BW, kg } \\
\hline d 5 (initial BW) & 43.02 & 42.90 & 1.12 & 0.94 \\
\hline$d 25$ & 49.11 & 48.64 & 0.37 & 0.37 \\
\hline d 46 & 60.96 & 61.81 & 0.81 & 0.46 \\
\hline \multicolumn{5}{|l|}{ BW gain, g/calf/d } \\
\hline 5 to $25 \mathrm{~d}$ & 293.1 & 270.5 & 17.4 & 0.36 \\
\hline 26 to $46 \mathrm{~d}$ & 564.2 & 627.4 & 36.1 & 0.22 \\
\hline 5 to $46 \mathrm{~d}$ & 428.5 & 448.9 & 19.4 & 0.46 \\
\hline \multicolumn{5}{|c|}{ Height at withers, $\mathrm{cm}$} \\
\hline d 5 & 76.6 & 76.9 & 0.6 & 0.69 \\
\hline d 46 & 83.1 & 83.1 & 0.4 & 0.98 \\
\hline \multicolumn{5}{|l|}{ Heart girth, cm } \\
\hline d 5 & 80.9 & 80.0 & 0.7 & 0.41 \\
\hline$d 46$ & 89.6 & 90.6 & 0.6 & 0.30 \\
\hline \multicolumn{5}{|c|}{ Withers to pins, $\mathrm{cm}$} \\
\hline d 5 & 59.4 & 59.9 & 0.6 & 0.55 \\
\hline d 46 & 68.1 & 69.0 & 0.5 & 0.16 \\
\hline \multicolumn{5}{|c|}{ Point of shoulder to pins, $\mathrm{cm}$} \\
\hline d 5 & 69.9 & 70.4 & 0.8 & 0.66 \\
\hline$d 46$ & 79.7 & 80.6 & 0.6 & 0.32 \\
\hline \multicolumn{5}{|c|}{ Feed efficiency, kg DM/kg BW gain } \\
\hline 5 to $25 \mathrm{~d}$ & 2.15 & 2.46 & 0.19 & 0.26 \\
\hline 26 to $46 \mathrm{~d}$ & 1.57 & 1.54 & 0.05 & 0.68 \\
\hline 5 to $46 \mathrm{~d}$ & 1.70 & 1.73 & 0.05 & 0.69 \\
\hline
\end{tabular}

\section{Calf health}

Two calves in MOS group died, the first one at $25 \mathrm{~d}$ of age and the other at $37 \mathrm{~d}$ of age and were replaced. The cause of death of the first calf was not determined. The other calf which died was submitted to Bornova (Izmir) Institute for Veterinary Control and Research of the Ministry of Agriculture and Rural Affairs of the Republic of Turkey. Pathological investigation showed that the death could be related to asphyxia resulting from lungs edema.

No respiratory problems in calves in both groups occurred during the experiment. There were no differences in fecal fluidity scores for d 5 to 25 , d 26 to 46 , and d 5 to 46 between the groups in the study (Table 4). Percent calf days with scours and percent calf days treated for scours in various age periods were also unaffected by treatment. Percent calf days with scours in MOS group for $\mathrm{d} 26$ to 46 was numerically lower than for control group (12.62\% vs. $18.33 \%)$. No marked difference in cost of antibiotics used for treatment of calf scours existed between the groups. Nevertheless, calf scours was a common problem especially during the first 3 weeks of the experiment as seen in Table 4 . From 5 to $25 \mathrm{~d}$ of age, 16 calves in control group and 15 calves in MOS group were treated for scour-related disorders. The reason for the high number of calves being treated for scours may have been that calf scours had been a common problem at the location of the experiment for many years. This suggests that there 
must have been a significant enteric challenge for calves at this location. Even under these stressful conditions, MOS in whole milk did not elicit an improvement in enteric health in the circumstances of this location.

Hill et al. (2008) also found that addition of MOS or FOS to MR did not reduce fecal score and days with abnormal fecal scores (scouring) in calves. Moreover, they reported that calves fed MOS in MR tended to have more abnormal fecal score days than calves fed no MOS in MR. Terré et al. (2007) found no differences in the incidence of loose feces, and in the number of days on medical or oral rehydratant treatment of calves fed MR with MOS or no additive. Newman et al. (1993) reported no difference in concentrations of fecal coliforms or clostridia, and Terré et al. (2007) reported no difference in Escherichia coli fecal counts between calves fed MR with MOS or no supplementation. On the other hand, Nippei Feed Company (1996) reported that addition of MOS to MR reduced scours in calves. Heinrichs et al. (2003) found that addition of MOS or antibiotics to MR increased the probability of normal scores for fecal fluidity, scours severity, and fecal consistency as compared to control calves. Quigley et al. (1997) showed that fecal score and number of days scouring tended to be reduced when calves were fed MR supplemented with galactosyl-lactose. Quigley et al. (2002) found that fecal scores, days with scours, and use of antibiotics and electrolytes were reduced when calves were fed additive containing spray-dried bovine serum and FOS in MR.

Table 4

Least squares means for fecal fluidity score, days with scours and days treated for scours of calves for various age periods

\begin{tabular}{|c|c|c|c|c|}
\hline Trait & Control & MOS & SE & $P$ \\
\hline No. of calves & 20 & 20 & & \\
\hline \multicolumn{5}{|l|}{ Fecal fluidity score ${ }^{1}$} \\
\hline 5 to $25 d$ & 2.29 & 2.35 & 0.05 & 0.44 \\
\hline 26 to $46 \mathrm{~d}$ & 2.07 & 2.02 & 0.07 & 0.67 \\
\hline 5 to $46 \mathrm{~d}$ & 2.18 & 2.19 & 0.05 & 0.92 \\
\hline \multicolumn{5}{|l|}{ Calf days with scours, $\%^{2}$} \\
\hline 5 to $25 \mathrm{~d}$ & 30.48 & 30.71 & 3.49 & 0.96 \\
\hline 26 to $46 \mathrm{~d}$ & 18.33 & 12.62 & 3.89 & 0.31 \\
\hline 5 to $46 \mathrm{~d}$ & 24.40 & 21.67 & 3.03 & 0.53 \\
\hline \multicolumn{5}{|l|}{ Calf days treated for scours, $\%^{3}$} \\
\hline 5 to $25 \mathrm{~d}$ & 15.48 & 18.81 & 2.47 & 0.35 \\
\hline 26 to $46 \mathrm{~d}$ & 2.62 & 0.48 & 1.41 & 0.29 \\
\hline 5 to $46 \mathrm{~d}$ & 9.05 & 9.64 & 1.43 & 0.77 \\
\hline \multicolumn{5}{|l|}{ No. of calves treated for scours } \\
\hline 5 to $25 d$ & 16 & 15 & & \\
\hline 26 to $46 \mathrm{~d}$ & 2 & 1 & & \\
\hline \multicolumn{5}{|l|}{ Drug cost per calf, Euro ${ }^{4}$} \\
\hline 5 to $25 \mathrm{~d}$, antibiotics & 6.40 & 7.71 & & \\
\hline 5 to $25 \mathrm{~d}$, other (vitamins etc.) & 0.08 & 0.21 & & \\
\hline 26 to $46 \mathrm{~d}$, antibiotics & 1.21 & 0.18 & & \\
\hline 26 to $46 \mathrm{~d}$, other & 0.11 & 0.00 & & \\
\hline 5 to $46 \mathrm{~d}$, antibiotics & 7.61 & 7.89 & & \\
\hline 5 to $46 \mathrm{~d}$, other & 0.19 & 0.21 & & \\
\hline
\end{tabular}

${ }^{1}$ Fecal fluidity score, $1=$ normal, $2=$ soft, $3=$ runny, $4=$ watery, ${ }^{2}$ Percent days with a fecal fluidity score of $\geq 3$, ${ }^{3}$ Percent days treated for scours, ${ }^{4}$ Total drug cost in each group was divided by 20 (calves). 
The effect of sex was not significant on any of the traits in this study $(P>0.10)$, and no sex by treatment interactions were present.

In conclusion, addition of MOS to warm whole milk did not affect feed intake, BW gain, skeletal growth, feed efficiency, fecal fluidity score, percent calf days with scours, and percent calf days treated for scours in Holstein calves in a 6-week experiment. However, starter intake and consequently BW gain from 26 to $46 \mathrm{~d}$ of age tended to be improved in calves in MOS group compared with calves in control group. Further research efforts should continue to determine the physiological effect of MOS on performance and health of calves.

\section{Acknowledgements}

The authors wish to thank Alltech, Inc., Turkey for the partial financial support; and thank Tarık Ayyılmaz \& Berkan Bertan for their assistance during the experiment.

\section{References}

Ardalan M, Dehghan-Banadaky M, Rezayazdi K (2010) Milk yield persistency and its relationship with health problems in Holstein dairy cows supplemented with different levels of ruminally protected methionine and choline. Arch Tierz 53, 266-276

Ayışığı K, Ataşoğlu C, Yurtman IY, Mendeş M, Pala A (2005) Effect of probiotic supplementation shortly before and after weaning on growth of Turkish Saanen kids. Arch Tierz 48, 601-611

Dvorak RA, Jacques KA, Newman KE (1997a) Effect of adding mannan oligosaccharide (Bio-Mos) to the milk replacer for calves. J Anim Sci 75 Suppl 1, 22

Dvorak RA, Newman KE, Jacques KA, Waterman DF (1997b) Effects of Bio-Mos added to calf starter and an all-milk milk replacer on performance and health. Poster presented at Dairy Science, Guelph, Ontario, CA, June 1997

Fairchild AS, Grimes JL, Jones FT, Wineland MJ, Edens FW, Sefton AE (2001) Effects of hen age, Bio-Mos ${ }^{\circledR}$ and Flavomycin ${ }^{\oplus}$ on poult susceptibility to oral Escherichia coli challenge. Poultry Sci 80, 562-571

Grieshop CM (2003) The interaction of nutrition and the immune system: a discussion on the role of energy, protein, and oligosaccharides. Pages 499-507 in: Nutritional Biotechnology in the Feed and Food Industries. Proc. Alltech's 19th Annual Symposium. TP Lyons and KA Jacques, ed. Nottingham University Press, Nottingham, UK

Harvey WR (1987) User's Guide for LSMLMW PC-1 Version. Mixed Model Least-Squares and Maximum Likelihood Computer Program. Columbus, Ohio, USA

Heinrichs AJ, Jones CM, Heinrichs BS (2003) Effects of mannan oligosaccharide or antibiotics in neonatal diets on health and growth of dairy calves. J Dairy Sci 86, 4064-4069

Heinrichs AJ, Wells SJ, Losinger WC (1995) A study of the use of milk replacers for dairy calves in the United States. J Dairy Sci 78, 2831-2837

Hill TM, Bateman II HG, Aldrich JM, Schlotterbeck RL (2008) Oligosaccharides for dairy calves. Prof Anim Sci $24,460-464$

Holló G, Ender K, Lóki K, Seregi J, Holló I, Nuernberg K (2008) Carcass characteristics and meat quality of Hungarian Simmental young bulls fed different forage to concentrate ratios with or without linseed supplementation. Arch Tierz 51, 517-530

Jacques KA, Newman KE (1994) Effect of oligosaccharide supplements to milk replacer on calf performance and health pre-weaning. J Anim Sci 72 Suppl 1/J Dairy Sci 77 Suppl 1, 295

Kaufhold J, Hammon HM, Blum JW (2000) Fructo-oligosaccharide supplementation: Effects on metabolic, endocrine and hematological traits in veal calves. J Vet Med A 47, 17-29 
Larson LL, Owen FG, Albright JL, Appleman RD, Lamb RC, Muller LD (1977) Guidelines toward more uniformity in measuring and reporting calf experimental data. J Dairy Sci 60, 989-991

Naumann K, Bassler R (1993) The chemical analysis of feeding stuff. VDLUFA-Methodenbuch 3, VDLUFAVerlag, Damstadt, Germany [in German]

Newman K (2002a) Bio-Mos: Opportunities for improving calf production? Feed Compounder, June/July 2002, $17-20$

Newman M (2002b) Antibiotic resistance is a reality: novel techniques for overcoming antibiotic resistance when using new growth promoters. Pages 97-106 in: Nutritional Biotechnology in the Feed and Food Industries. Proc. Alltech's 18th Annual Symposium. TP Lyons and KA Jacques, ed. Nottingham University Press, Nottingham, UK

Newman KE, Jacques K, Buede RP (1993) Effect of mannan oligosaccharide supplementation of milk replacer on grain, performance and fecal bacteria of Holstein calves. J Anim Sci 71 Suppl 1, 271

Nippei Feed Company (1996) Effect of Bio-Mos on performance and health of calves through six weeks of age. Poster presented at the 12th Annual Symposium on Biotechnology in the Feed Industry, April 1996

Oysun G (2001) Methods of Analysis for Milk and Milk Products. 3rd ed. Ege Üniv. Ziraat Fak. Yay. No: 504. E.Ü.Z.F. Ofset Atelyesi, Izmir-Turkey [in Turkish]

Parks CW, Grimes JL, Ferket PR, Fairchild AS (2001) The effect of mannanoligosaccharides, bambermycins, and virginiamycin on performance of large white male market turkeys. Poultry Sci 80, 718-723

Quigley III JD (2004) Calf Note \#103-Oligosaccharides as nutraceuticals for calves. http://www.calfnotes.com/ pdffiles/CN103.pdf [last accessed 23.08.2010]

Quigley III JD, Kost CJ, Wolfe TA (2002) Effects of spray-dried animal plasma in milk replacers or additives containing serum and oligosaccharides on growth and health of calves. J Dairy Sci 85, 413-421

Quigley III JD, Drewry JJ, Murray LM, Ivey SJ (1997) Body weight gain, feed efficiency, and fecal scores of dairy calves in response to galactosyl-lactose or antibiotics in milk replacers. J Dairy Sci 80, 1751-1754

Spring P, Wenk C, Dawson KA, Newman KE (2000) The effects of dietary mannanoligosaccharides on cecal parameters and the concentrations of enteric bacteria in the ceca of salmonella-challenged broiler chicks. Poultry Sci 79, 205-211

Terré M, Calvo MA, Adelantado C, Kocher A, Bach A (2007) Effects of mannan oligosaccharides on performance and microorganism fecal counts of calves following an enhanced-growth feeding program. Anim Feed Sci Tech 137, 115-125

Corresponding author:

Ibrahim Kaya

email: ibrahim.kaya@ege.edu.tr

Department of Animal Science, Faculty of Agriculture, Ege University, Bornova 35100 Izmir, Turkey 